\title{
KRITIK TERHADAP PENERAPAN PASAL 156a KUHP DITINJAU DARI PERSPEKTIF KEHIDUPAN DEMOKRASI DI INDONESIA
}

\author{
Dian Andriasari \\ Fakultas Hukum, Universitas Islam Bandung \\ email: adriasaridian@gmail.com
}

disampaikan 05/9/17 - di-review 12/11/17 - diterima 13/12/17

DOI: $10.25123 /$ vej.2688

\begin{abstract}
The implementation of Article 156 a Criminal Code on Blasphemy more often than not create and exacerbate social tension between different religious groups. In a number of blasphemy cases, the majority or dominant (religious) groups are portrayed as victims. Apparently, the dominant group views heavily influenced the way this article is interpreted and implemented. In other words, how and when blasphemy is committed by minority groups. This article, using a socio-juridical approach, shall examine how the implementation and interpretation of the blasphemy article, influences Indonesian democratic life.
\end{abstract}

Keywords:

Article 156 a Criminal Code; Blasphemy; Democracy.

\begin{abstract}
Abstrak
Penerapan ketentuan Pasal 156a KUHP tentang Penodaan Agama seringkali justru memunculkan dan memperluas ketegangan sosial dalam masyarakat. Dalam sejumlah kasus penerapan ketentuan pidana ini justru menargetkan kelompok minoritas sebagai pelaku dengan korban masyarakat penganut agama dominan. Dalam penerapan ketentuan tersebut ditengarai bahwa suara kelompok mayoritas sangat berpengaruh dalam menafsir ada/tidaknya tindak pidana penodaan agama. Tulisan ini, dengan menggunakan pendekatan yuridis sosiologis, akan menelaah pengaruh penerapan Pasal 156a KUHP terhadap kehidupan demokrasi Indonesia.
\end{abstract}

Kata kunci: Pasal 156a KUHP; penodaan agama; demokrasi.

\section{Pendahuluan}

Tatanan hukum yang beroperasi dalam suatu masyarakat pada dasarnya merupakan pengejawantahan cita hukum yang dianut dalam masyarakat yang bersangkutan ke dalam berbagai perangkat aturan hukum positif, lembaga hukum dan proses (perilaku birokrasi pemerintahan dan warga masyarakat). Adapun yang dimaksud dengan cita hukum adalah gagasan, karsa, cipta dan pikiran 
berkenaan dengan hukum atau persepsi tentang makna hukum yang dalam intinya terdiri dari tiga unsur; keadilan, kehasilgunaan dan kepastian hukum. ${ }^{1}$

Cita hukum bangsa Indonesia berakar dalam Pancasila dan ditetapkan sebagai landasan kefilsafatan dalam menata kerangka dan struktur dasar organisasi negara sebagaimana dirumuskan dalam konstitusi negara. Pandangan hidup Pancasila bertolak dari keyakinan bahwa alam semesta dengan segala isinya termasuk manusia, yang sebagai suatu keseluruhan terjalin secara harmonis diciptakan oleh Tuhan. Kehadiran manusia di dunia dikodratkan dalam kebersamaan dengan sesamanya, namun tiap manusia memilki kepribadian yang unik yang membedakan yang satu dari yang lain. ${ }^{2}$

Mengelola keberagaman adalah salah satu tantangan terbesar pada hampir semua pemerintah di banyak negara. Antara lain mengatur perbedaan agama para penduduknya, juga bagaimana melindungi kaum minoritas yang ada. Meskipun di Indonesia hanya ada 6 agama yang secara resmi diakui oleh pemerintah: Islam, Protestan, Katholik, Budha, Hindu, dan Konghucu, namun kenyataannya banyak sekali agama-agama yang berada dan berkembang di luar agama resmi itu. Dan ironisnya, meskipun reformasi dan demokratisasi di Indonesia pasca 1998 membawa angin kebebasan pada masyarakat, berbagai kasus dan kejadian yang berkaitan dengan isu atau tuduhan "penodaan agama" oleh kelompok minoritas juga meningkat. ${ }^{3}$

Keragaman dalam masyarakat, menyangkut bahasa, etnisitas, agama dan sebagainya adalah fakta kehidupan saat ini yang tak dapat diingkari. Kalaupun dalam suatu negara ada keseragaman dalam satu hal, ia akan beragam dalam halhal lain. Dalam pengertian ini, sulit atau bahkan mustahil menemukan suatu negara yang homogen. Dalam masyarakat demokratis yang majemuk, persoalan utama adalah bagaimana mengelola keragaman. ${ }^{4}$

Persoalan relasi negara dan agama merupakan persoalan yang banyak menimbulkan perdebatan. Ketegangan perdebatan tentang hubungan agama dan

1 Bernard Arif Sidharta, Ilmu Hukum Indonesia, Jakarta, Genta Punlishing, 2015, hlm. 1

2 Id, hlm.148

3 Melissa Crouch, Asia Pacific Bulettin, Number 146, January 26, 2012, hlm.3-4

4 Zainal Abidin Bagir, Pluralisme Kewargaan, Program CRCS UGM, Yogjakarta, 2016, hlm.38 
negara diilhami oleh konstelasi sosial dan budaya di Indonesia yang heterogen. Akan tetapi dalam konstitusi negara diatur. Negara mengatur secara tegas berkaitan dengan hak kebebasan beragama, yakni dalam Pasal 28E ayat (1) UUD 1945. Artinya secara konstitusional negara memiliki kewajiban untuk menjamin kebebasan beragama/berkeyakinan sebagaimana dijamin oleh konstitusi. Pemerintah juga telah meratifikasi Kovenan Internasional Hak-hak Sipil dan Politik, yang memberikan jaminan kebebasan beragama/berkeyakinan. ${ }^{5}$

Akan tetapi realitas menunjukkan fakta yang berlawanan, dalam laporan pemantauan kondisi kebebasan beragama/berkeyakinan di Indonesia hasil dari penelitian Setara Institute dan organisasi masyarakat sipil lainnya menunjukkan bahwa tingkat intoleransi, baik di masyarakat maupun di tubuh negara, melalui aparat negara, semakin menguat; sebaliknya, toleransi semakin melemah. Jumlah Peristiwa pada tahun 2016 meningkat secara signifikan (208 peristiwa pelanggaran kebebasan beragama/berkeyakinan dengan 270 tindakan ${ }^{6}$ dibanding peristiwa yang terdokumentasikan Setara Institute pada tahun 2015,Jumlah peristiwa pelanggaran yang terjadi sebanyak 196 peristiwa, sedangkan tindakan pelanggaran di angka 236 tindakan. $^{7}$

Konflik kekerasan berbasis isu agama dalam persepektif hukum (pidana) memiliki permasalahan mendasar, yakni dalam formulasi undang-undang hukum pidana yang merupakan bagian dari politik hukum pidana. Relevansi dari pelaksanaan politik hukum pidana berarti mengadakan pemilihan untuk mencapai hasil perundang-undangan pidana yang paling baik dalam arti memenuhi syarat keadilan dan daya guna ${ }^{8}$ atau dapat berupa usaha mewujudkan peraturan perundang-undangan pidana yang sesuai dengan keadaan dan situasi pada suatu waktu dan untuk masa-masa yang akan datang. ${ }^{9}$

5 Andriasari, Delik Agama; "Hegemoni Negara Terhadap Agama?", diposting dalam laman www.crcs.ugm,

${ }^{6}$ Jumlah peristiwa dengan jumlah tindakan berbeda, karena dalam satu peristiwa (incident/event) bisa saja terjadi berbagai bentuk tindakan (act). Disiplin hak asasi manusia membedakan antara peristiwa dan tindakan

7 Halili, Supremasi Intoleransi, Setara Press, Jakarta, 2011, hlm.11

8 Sudarto, Hukum dan Hukum Pidana, Bandung, Alumni, 1981, hlm.159

9 Id. 
Dalam beberapa kasus dimana hakim menjatuhkan putusan pemidanaan, seringkali belum mencerminkan rasa keadilan. Diantara sekian banyak kasus yang dijatuhi putusan pemidanaan dengan berdasarkan pada Pasal 156a KUHP adalah kasus Ahok. Kasus ini bergulir seiring dengan penyelenggaraan Pilkada DKI, sehingga arus opini yang bergulir bahwa kasus ini sarat intervensi politik menjadi sulit untuk dibantah. Hal yang menarik dari kasus ini manakala dakwaan JPU Pasal 156a Ke (1) KUHP, Hakim memutus secara ultra petita. Gelombang arus penolakan terhadap tuntutan Jaksa linier dengan arus dukungan dari kalangan ekstirmis kanan yang tak sabar agar Ahok mendekam di jeruji penjara. Namun salah satu tokoh cendikiawan Muslim, Buya Syafii Maarif meminta agar agama tidak dijadikan alat politik. Terkait adanya sejumlah ulama yang mendesak agar Ahok dipenjara, Buya berpandangan ulama itu bukan hanya satu orang saja.

Dalam kasus lain tuduhan sesat yang dialamatkan kepada Tajul Muluk salah satu tokoh Syiah di Sampang Madura. Meskipun pada prinsipnya persoalan perbedaan mazhab antara Sunni dan Syiah masih dan selalu hangat diperdebatkan hingga saat ini. Di kalangan Islam sendiri, kelompok Syiah tidak secara tegas dianggap sesat. Proses pengadilan terhadap Tajul Muluk pun dinilai tidak adil karena mestinya ia menjadi korban. Sebelumnya pada 29 Desember 2011, Tajul Muluk bersama 300 pengikut aliran Syiah diserang oleh 500 kelompok anti Syiah dan membakar rumah, sekolah serta pondok pesantren yang dikelolah Tajul Muluk. Atas insiden itu, hanya satu orang yang kemudian ditahan serta dihukum 3 bulan penjara. Vonis terhadap Tajul Muluk sangat timpang bila dibanding dengan vonis terhadap pelaku kekerasan terhadap penganut agama atau aliran lain. Pelaku penyerangan yang benar-benar mengancam kebebasan dan toleransi serta melakukan tindakan kekerasan dihukum sangat ringan. Hukuman terhadap Tajul Muluk juga mempertegas fakta makin besarnya ancaman terhadap kekebasan dan ruang gerak masyarakat dalam mengekspresikan diri.

Dalam hal ini justru yang seharusnya dikualifikasi sebagai korban seringkali duduk di kursi terdakwa. Seringkali hakim mengabaikan fakta-fakta hukum yang nyata. Arus narasi opini masyarakat mayoritas menjadi justifikasi hakim untuk meneguhkan apakah kemudian ia yakin terdakwa telah benar-benar 
melakukan penodaan terhadap agama. Spekulasi ini tidak dapat dihindarkan apabila menelisik setiap putusan-putusan yang mengancamkan pasal penodaan agama, faktanya hampir seluruh terdakwa gagal lepas dari jerat surat dakwaan.

Hingga saat ini meskipun apa yang disebut sebagai UU Penistaan Agama -Dekrit Presiden No.1/PNPS/1965 dan KUHPidana Pasal 156a- "hanya" digunakan untuk mengadili sekitar 10 orang antara tahun 1965-1998, tetapi menurut catatan Amnesti International terdapat 106 orang yang diadili dan dihukum dengan menggunakan aturan itu antara tahun 2005-2014. ${ }^{10}$

Realitas saat ini menunjukkan bahwa pasal ini terus digunakan untuk memenjarakan orang selama lima tahun, hanya karena mereka secara damai menggunakan hak berekspresi atau hak untuk beragama. Pasal ini sering digunakan untuk menjerat orang-orang dari golongan agama minoritas, aliran kepercayaan dan pemikiran, dan sebagian dari mereka yang menafsirkan satu agama dengan tafsiran yang tidak disetujui oleh pemerintah atau segolongan mayoritas. Sebagai contoh vonis terhadap Tajul Muluk, sesungguhnya telah melanggar ketentuan yang mengikat secara hukum terhadap kebebasan berekspresi, berkeyakinan, beragama, kesetaraan di depan hukum dan kebebasan dari diskriminasi.

Menyoal penerapan pasal penodaan agama yang seringkali menimbulkan ambiguitas dan persoalan baru di masyarakat, meski sebenarnya bagaimana memahami "penodaan" yang berimplikasi pada peristiwa kekerasan atas nama agama, adalah sebuah konstruksi sosial yang seyogyanya dipahami secara holistik. Tentang paham dan tindakan keagamaan yang dilakukan oleh golongan agama tertentu, apakah tepat apabila silang sengketa perbedaan tafsir kemudian diseret ke ranah hukum pidana. Karena dalam diri "pelakunya”, ini merupakan tindakan yang sesuai ajarannya dan merupakan bentuk respon sosial terhadap realitas

\footnotetext{
10 http://nasional.kompas.com/read/2017/05/12/17225441/kritik.badan.dunia.soal.pasal. penodaan.agama.ini.tanggapan.polri
} 
sosial yang dikonstruksi sebagai "menyimpang" dari ajaran agama yang benar dalam reprsentasi mayoritas dan politik. ${ }^{11}$

Dalam menafsirkan suatu perbuatan termasuk dalam kategori penodaan agama, penegak hukum khususnya jaksa dan hakim sangat tergantung dengan keterangan dari para ahli yang memberikan keterangan di pengadilan. Hal ini dikarenakan dalam rumusan tindak pidana sendiri tidak terdapat suatu penjelasan dan penafsiran yang cukup jelas tentang perbuatan-perbuatan yang tergolong sebagai penodaan terhadap agama. Sehingga tidak terdapat suatu pemisahan yang jelas apakah suatu perbuatan tergolong dalam penafsiran yang menyimpang atau penyesatan atau berisikan permusuhan dll. 12

Pada kasus-kasus yang dianalisis, individu yang dijadikan sebagai ahli untuk memberikan keterangan dalam menentukan apakah terjadi penodaan agama atau tidak diantaranya adalah ahli hukum pidana, perwakilan dari Majelis Ulama Indonesia bahkan FPI, sedangkan berdasarkan data yang ada FPI adalah pelaku tindakan intoleran paling tinggi termasuk MUI. Permasalahan yang mengemukan di sini individu yang ditempatkan sebagai ahli untuk memberikan keterangan apakah suatu perbuatan tergolong dalam penodaan agama atau tindak pidanaterhadap agama lainnya seringkali tidak dijelaskan secara detil mengenai latar belakang keahlian yang dimiliki dan sejauh mana pengalaman yang pernah dilakukan dalam melakukan pengkajian terhadap agama yang menjadi objek permasalahan. Akan tetapi di sisi lain pihak penasihat hukum juga tidak terlalu mempermasalahkan individu yang dijadikan ahli di muka persidangan. Hal ini menjadi suatu analisis yang perlu didiskusikan lebih lanjut mengingat dalam kasus-kasus penodaan agama yang ada, keterangan yang disampaikan oleh ahli menjadi faktor penentu sebagai sarana pembuktian untuk menentukan apakah perbuatan yang dilakukan oleh terdakwa adalah tindak pidana terhadap agama

\footnotetext{
11 Taufik Amin Nur Wijaya, Hubungan Antara Islam Radikal Dan Terorisme, Kajian Timur Tengah Agama Dan Lintas Budaya Universitas Gadjah Mada 2014, Hlm. 34.

12 http://www.lbhbandung.or.id/media/2017/03/Analisis-Pasal-156-a-KUHP-dan-UU-No-1tahun-1965-terkait-tindak-pidana-penodaan-agama-yang-terjadi-di-Jawa-Barat.pdf, diakses pada tanggal 07/10/2017, pukul 08.06 WIB
} 
(penodaan atau penyesatan agama) dan dijadikan sebagai bahan pertimbangan oleh hakim untuk menjatuhkan pidana terhadap terdakwa. ${ }^{13}$

Oleh sebab itu dari beberapa persoalan yang melatarbelakangi realitas penerapan Pasal 156a KUHP di Indonesia, menarik untuk dikaji lebih mendalam. Dalam hal ini penulis ingin membatasi pembahasan menjadi beberapa permasalahan yakni bagaimana pengaruh penerapan Pasal 156a KUHP dalam kehidupan demokrasi di Indonesia dan bagaimana prospek pengaturan rumusan delik agama dalam perspektif ius constituendum.

Dengan menggunakan metode penelitian yuridis sosiologis, yaitu metode yang menekankan pada ilmu hukum (yuridis) tetapi disamping itu juga berusaha menelaah kaidah-kaidah hukum yang berlaku dalam masyarakat. ${ }^{14}$ Penggunaan pendekatan tersebut merupakan salah satu strategi untuk memahami kompleksitas dunia nyata. Sebagaimana dikatakan Patton, paradigma baru selalu dibutuhkan, agar dapat diketahui apa yang penting, absah dan masuk akal. Paradigma baru juga bersifat normatif, menunjukkan kepada praktisinya apa yang harus dilakukan tanpa perlu melakukan pertimbangan eksistensial atau epistemologis yang panjang. ${ }^{15}$

\section{Pembahasan}

\section{Pengaruh Penerapan Pasal 156a KUHP Dalam Kehidupan Demokrasi Di Indonesia}

Agama dan negara memiliki relasi yang erat dan tidak bisa dipisahkan dengan kehidupan masyarakat. Dalam mukadimah Undang-undang Dasar 1945, alinea ketiga disebutkan "Atas berkat rahmat Allah Yang Maha Kuasa dan dengan didorongkan oleh keinginan luhur, supaya berkehidupan kebangsaan yang bebas, maka rakyat Indonesia menyatakan dengan ini kemerdekaannya". Kalimat pembuka dalam alinea ketiga mukadimah UUD 1945 merupakan representasi dari

\footnotetext{
${ }^{13} \mathrm{Id}$

${ }^{14}$ Ronny Hanitijo, Metodologi Penelitian Hukum dan Jurimetri, Galia Indonesia, cet ke-4, Jakarta. $1990 \mathrm{hlm} .35$

${ }^{15}$ Deddy Mulyana, Metode penelitian kualitatif, Paradigma baru ilmu komunikasi dan ilmu sosial lainnya, Bandung, Rosda, 2003, hlm.3
} 
pengakuan negara terhadap eksistensi agama, meskipun Indonesia secara tegas mengkonsepsikan diri sebagai negara kesatuan yang mempunyai semboyan bhineka tunggal ika, artinya mengakui keragaman, Indonesia merupakan suatu bangsa yang multi etnis, multi religius dengan segala keragaman identitas yang melekat didalamnya. ${ }^{16}$

Menurut Koentjaraningrat ${ }^{17}$, agama merupakan suatu sistem yang terdiri atas empat komponen:

1. emosi keagamaan yang menyebabkan manusia itu bersikap religius;

2. sistem keyakinan yang mengandung segala keyakinan serta bayangan manusia tentang sifat-sifat Tuhan, wujud alam gaib, serta segala nilai, norma, dan ajaran dari religi yang bersangkutan;

3. sistem ritus dan upacara yang merupakan usaha manusia untuk mencari hubungan dengan Tuhan, dewa-dewa atau makhluk halus yang mendiami alam gaib;

4. umat atau kesatuan sosial yang menganut sistem keyakinan tersebut butir $b$, dan yang melakukan sistem ritus dan upacara tersebut butir c.

Dalam UUD 1945 terdapat beberapa ketentuan yang memberikan jaminan atas hak warga negara untuk beragama dan berkeyakinan. Setidaknya terdapat dua pasal dalam UUD 1956 yang dapat diidentifikasi sebagai pasal yang memberikan jaminan secara langsung atas kebebasan beragama bagi setiap orang, baik warga negara maupun bukan. Dua ketentuan tersebut adalah Pasal 28E dan Pasal 28I yang berbunyi sebagai berikut:

Pasal 28 E UUD 1945

1. Setiap orang bebas memeluk agama dan beribadat menurut agamanya, memilih pendidikan dan pengajaran, memilih pekerjaan, memilih kewarganegaraan dan tempat tinggal di wilayah negara dan meninggalkannya serta berhak kembali.

\footnotetext{
${ }^{16}$ Supra no 5

${ }^{17}$ Koentjaraningrat, Kebudayaan, Mentalitas, Dan Pembangunan, Gramedia, Jakarta, 1985 hlm 144145
} 
2. Setiap orang berhak atas kebebasan meyakini kepercayaan, menyatakan pikiran dan sikap sesuat dengan hati nuraninya.

Pasal 28 E UUD 1945 memberikan jaminan bagi siapapun untuk memeluk agama dan keyakinan dan/atau kepercayaannya secara bebas. Ketentuan tersebut secara implisit mendeklarasikan kebebasan bagi siapa saja untuk beragama dan berkeyakinan. Pada saat bersamaan, jaminan kebebasan beragama juga disempurnakan dengan jaminan bagi setiap orang untuk beribadan menurut agama dan keyakinannya. Upaya tersebut merupakan implementasi semangat demokrasi yang tercermin dalam regulasi.

Dalam pelaksanaannya, demokrasi sangat membutuhkan berbagai lembaga sosial dan politik yang dapat menopang bagi keberlangsungan suatu sistem demokrasi yang baik. Terdapat beberapa lembaga yang dibutuhkan dalam penerapan sistem demokrasi ini, diantaranya adalah;

1. Para pejabat yang dipilih, pemegang kendali terhadap segala keputusan pemerintahan mengenai kebijakan secara konstitusional (demokrasi konstitusional)

2. Pemilu yang jujur dan adil

3. Kebebasan berpendapat

4. Akses-akses informasi alternatif

5. Otonomi asosiasional, yakni warga negara berhak membentuk perkumpulan-perkumpulan aatu organisasi-organisasi yang relatif bebas, termasuk partai politik dan kelompok kepentingan

6. Hak warga negara yang inklusif

Sementara konstitusi dan hukum menjadi aturan-aturan formal negara, pilar lain adalah suatu kultur kewargaan yang dihidupi warga negara. Pilar ini perlu ditekankan secara khusus, karena dalam banyak kasus, proses demokratisasi tidak dapat berjalan berkelanjutan ketika tidak ditopang oleh kultur kewargaan. Dalam situasi itu, demokratisasi hanya menghasilkan kelembagaan baru, namun tidak diikuti perubahan perilaku yang demokratis, 
bahkan dalam perjalanan selanjutnya dapat mendelegitimasi atau menghilangkan kepercayaan pada institusi demokrasi yang dibangun. ${ }^{18}$

Dalam mengelola keragaman, demokrasi menawarkan dua model, yakni melalui partisipasi dan kompetisi. Partisipasi menyangkut keterlibatan warga negara dalam proses pengambilan keputusan tentang hidup bersama dan setelah itu diikuti dengan kontestasi ide-ide yang akan dipilih melalui mekanisme pemilihan. Representasi diperlukan untuk menghadirkan aspirasi warga negara dalam ranah publik. Di Indonesia, representasi atau perwakilan seringkali hanya merujuk pada fungsi artikulasi dan agregasi kepentingan yang dijalankan oleh lembaga perwakilan formal (parlemen). Namun sesungguhnya, sebagaimana ditunjukkan Hannah Pitikin ${ }^{19}$ ada empat wajah representasi; representasi formalistik, simbolik, deskriptif dan substantif.

Secara umum hubungan antar agama di Indonesia berjalan baik di hampir seluruh wilayah Indonesia, meskipun tidak bisa dipungkiri masih ada beberapa masalah. Dalam beberapa tahun terakhir, khususnya setelah reformasi 1998, ada sumber-sumber ketegangan dalam hubungan antar komunitas agama, yang tak jarang berubah menjadi kekerasan. Kekerasan komunal ini melibatkan komunitaskomunitas beda agama dalam skala besar, seperti kasus yang terjadi di sekitar 1998. Namun saat ini yang seringkali muncul adalah isu penyesatan, baik terhadap kelompok dalam suatu agama ataupun kelompok-kelompok keagamaan baru. Ketegangan tersebut mengarah pada penggunaan kekerasan oleh kelompokkelompok masyarakat tertentu ${ }^{20}$ dan disorganisasi sosial. ${ }^{21}$

\footnotetext{
${ }^{18}$ Supra no 4, hlm. 39

${ }^{19}$ Hannah Pitkin, The Concept Of Repsesentation, Berkley University Of California, 1967, hlm 88

${ }^{20}$ Supra no 4, hlm.12

${ }^{21}$ Disorganisasi sosial biasa berupa "sebab", dan bisa merupakan "akibat". Disorganisasi sosial mengakibatkan runtuhnya fungsi pengontrol dari lembaga/institusi sosial dan memberikan kemungkinan kepada individu-individu untuk bertingkah laku semua sendiri tanpa kendali, tanpa kontrol, dan tanpa penggunaan pola susila tertentu. Lenyapnya fungsi pengontrol dari institusi masyarakat dan kemunculan formalisme tadi, sehingga lembaga tersebut berfungsi secara eksternal di luar individu, menyebabkan ditinggalkannya individu-individu secara internal tanpa bimbingan dan tanpa pola umum. Hal ini, jelas mengembangkan disorgansisasi sosial, dalam mana norma-norma institusional kehilangan sama sekali efektivitasnya. Agama adalah suatu sistem kepercayaan kepada Tuhan yang dianut oleh sekelompok manusia dengan selalu mengadakan interaksi denganNya. Pokok persoalan yang dibahas dalam agama adalah eksistensi Tuhan, manusia dan hubungan antara manusia dengan Tuhan. Tuhan dan hubungan
} 
Perkembangan selanjutnya dalam praktik demokrasi di beberapa negara menunjukkan bahwa kehidupan bersama dalam masyarakat majemuk bisa berdiri jika ditopang oleh beberapa pilar. Pilar pertama adalah konstitusi. Konstitusi negara demokratis dicirikan dengan adanya prinsip akuntabilitas yang mengontrol perimbangan kekuasaan dan penerimaan/pengakuan hak-hak warga negara (hak sipil, politik, sosial, ekonomi dan kultural). Proses mencapai cita negara demokrasi juga bertumpu pada pengembanan cita hukum sebuah negara, hukum yang melahirkan regulasi guna mewujudkan perlindungan dan ketertiban sosial. ${ }^{22}$

Salah satu model bagaimana posisi negara dalam menjamin kebebasan beragama warga negara, tercermin dalam konstitusi negara Australia. Kebebasan agama dijamin oleh pasal 116 Undang- Undang Dasar Australia, yang melarang pemerintah federal untuk membuat undang-undang mendirikan agama, memaksakan ajaran agama, atau melarang pelaksanaan ajaran agama dengan bebas. Orang bebas menyatakan keanekaragaman pandangan, selama mereka tidak memancing kebencian agama. Pemerintah Australia juga berbulat hati mendorong saling menghormati, pemahaman dan toleransi antar berbagai agama dan budaya di Australia dan di seluruh kawasan. Australia telah memupuk kerja sama antar-agama di kawasan melalui keterlibatannya di Dialog Antar -Agama Kawasan- suatu proses yang Australia sponsori bersama dengan Indonesia, Selandia Baru dan Filipina. Dialog ini menghimpun para pemimpin dari banyak agama di kawasan untuk berbagi pengalaman dan mengidentifikasi cara untuk memajukan perdamaian dan pengertian. Dialog pertama diadakan di Indonesia pada 2004, dan dua dialog lagi juga telah diselenggarakan (di Filipina pada 2006 dan Selandia Baru pada 2007). Kampuchea akan menyelenggarakan Dialog AntarAgama Kawasan keempat pada 2008. Agama atau aliran kepercayaan paling awal

manusia denganNya merupakan aspek metafisika, sedangkan manusia sebagai makhluk dan bagian dari benda alam termasuk dalam kategori fisika. Namun realitas saat ini agama dapat menjadi faktor penimbul konfik sosial.

${ }^{22}$ http://crcs.ugm.ac.id/id/artikel/10370/delik-agama-bagaimana-negara-melindungiagama.html 
Australia bermula dengan Penduduk Asli Australia, yang telah mendiami Australia selama lebih dari 40.000 tahun. ${ }^{23}$

Konstitusi Australia telah menempatkan kemajemukan masyarakat menjadi pondasi sekaligus rambu-rambu yang ketat dalam membangun rancangan konstitusi yang berpihak pada keberagaman dan merekognisi perbedaan sekecil apapun. Persoalan mendasar dalam mengelola keberagaman adalah bahwa sejauhmana keragaman tersebut dapat diterima diruang publik. Seperti ungkapan Hefner, kelebihan penggunaaan istilah "pluralisme kewargaan" adalah untuk menunjukkan bahwa demokrasi tak serta merta berarti demokrasi liberal, tetapi bisa pula memberikan ruang yang lebih besar bagi nilai-nilai publik, termasuk yang berasal dari agama, bukannya tidak diakui, namun masih tampak sangat terbatas.

Secara konseptual, demokrasi adalah sistem tata kelola kekuasaan yang dijalankan oleh pemerintahan oleh mayoritas (majority rule) dengan memberikan jaminan perlindungan terhadap hak-hak minoritas (minority rights). Hak asasi manusia (HAM), termasuk hak-hak minoritas, merupakan bagian intrinsik dari demokrasi. ${ }^{24}$ Dengan demikian sebagai negara yang mengkonsepsikan "demokratis", Indonesia seharusnya menjadikan hak minoritas sebagai bagian tak terpisahkan dari sistem politik, hukum dan sosial di dalamnya.

Pasal 27 International Covenant on Civil and Political Rights (ICPPR) yang sudah diratifikasi menjadi UU No.12 Tahun 2005, menjamin secara khusus hakhak minoritas. Sehingga agenda penegakannya sudah seharusnya menjadi concern semua pihak agar hukum tidak semata-mata menjadi pelindung bagi mereka yang secara antropologis dianggap sebagai minoritas.

Sementara konstitusi dan hukum menjadi aturan-aturan formal negara, pilar lain adalah suatu kultur kewargaan yang dihidupi warga negara. Pilar ini perlu ditekankan secara khusus, karena dalam banyak kasus, proses demokratisasi tidak dapat berjalan berkelanjutan ketika tidak ditopang oleh

\footnotetext{
23 http://indonesia.embassy.gov.au/jaktindonesian/kebebasan_beragama.html, dikutip pada tanggal 22 Agustus 2017, Pukul 12.10 WIB

24 David Betham, Democracy and Human Rights , Cambridge and Malden: Polity Press, 2000, hlm.93
} 
kultur kewargaan. Dalam situasi itu, demokratisasi hanya menghasilkan kelembagaan baru, namun tidak diikuti perubahan perilaku yang demokratis, bahkan dalam perjalanan selanjutnya dapat mendelegitimasi atau menghilangkan kepercayaan pada institusi demokrasi yang dibangun. ${ }^{25}$

Ketertiban sosial menjadi terancam manakala kekerasan atas nama agama terjadi. Residu dari rangkaian peristiwa tersebut kemudian berakhir dengan menggunakan hukum (pidana) sebagai media untuk menyelesaikan peristiwa kekerasan tersebut. Hal yang menarik adalah bahwa hukum pidana bekerja melalui mekanisme sistem peradilan pidana yang memiliki banyak keterbatasan, salah satu keterbatasan tersebut adalah kemampuan hukum pidana untuk mengurai akar kekerasan. Ketertiban sosial gagal dihadirkan kembali meskipun Pasal 156a KUHP telah berkali-kali dijatuhkan. Pasal tersebut seringkali menjadi pedang bermata dua.

Sebagian realitas tersebut terkristalisasi dalam kecemasan luar biasa di antara banyak orang ketika berbicara tentang agama, di antara banyak peristiwa, salah satunya adalah kasus ahok. Ada sederet nama lain yang juga mendapat label sebagai penoda agama. Mereka adalah Lia Eden, Abdul Rahman, Ahmad Musadeq dan kawan-kawan yang merupakan eks Pimpinan Gafatar, Hans Bague Jassin, Arswendo Atmowiloto, Saleh, Ardi Husein, Sumardin Tapaya, Yusman Roy, Mangapin Sibuea yang merupakan Pimpinan Sekte Kiamat. Peristiwa lalu yakni Aksi 212 terpenuhi dengan masuknya Ahok ke penjara, namun ketegangan belum berakhir. Tak sedikit pengamat atau orang awam yang melihat bahwa demokrasi pluralis ala Indonesia ternyata telah gagal ujian, dan Islam moderat sedang runtuh, digantikan Islam konservatif atau intoleran, bahkan radikal.

Adanya jaminan konstitusi dalam UUD 1945 menunjukkan bahwa hak beragama atau pemelukan suatu agama oleh seseorang merupakan hak asasi manusia yang sifatnya sangat esensial. Dalam bahasa yang lebih tegas dapat dinyatakan bahwa hak beragama itu adalah hak yang paling asasi dari semua hak asasi manusia. Disamping itu, hak beragama bukan pemberian negara, bukan

25 Supra no 4, hlm. 39 
pemberian golongan, karena itu negara tidak bisa mewajibkan warganya atau bahkan negara tidak boleh ikut campur terhadap persoalan agama warga negaranya masing-masing. ${ }^{26}$

Pasal penodaan agama merupakan ketentuan yang melanggar hak warga negara untuk menyatakan pendapat dan pikiran secara bebas seperti yang telah diatur di dalam Undang-Undang Dasar Tahun 1945, dan aturan lainnya. Tak hanya melanggar kebebasan berekspresi, penggunaan pasal penodaan agama juga berpotensi mengancam eksistensi kelompok minoritas di Indonesia. Pasalnya, kelompok minoritas kerap kali menjadi korban kriminalisasi kelompok mayoritas karena dianggap menyalahi ketentuan agama yang dianut kelompok mayoritas seperti yang terjadi dengan kelompok Gafatar, Ahamdiyah, dan lainnya.

Bahwa seharusnya demokrasi mencerminkan cita hukum. Hakikat hukum tersebut selalu bertumpu pada ide keadilan dan kekuatan moral, ide keadilan tidak pernah lepas dari kaitan hukum, sebab membicarakan hukum, jelas atau samar-samar senantiasa merupakan pembicaraan mengenai keadilan ${ }^{27}$. Kekuatan moral pun adalah unsur hakikat hukum, sebab tanpa adanya moralitas, maka akan kehilangan supremasi dan ciri independensinya, keadilan dan ketidakadilan menurut hukum akan diukur dan dinilai oleh moralitas yang mengacu pada harkat dan martabat manusia. ${ }^{28}$

Problem dari penerapan pasal penodaan dalam KUHP terpusat pada persoalan inkongruensi regulasi. Titik lemah sentral dalam ketidaksebangunan jaminan kebebasan beragama/berkeyakinan. Undang-undang Nomor 1/PNPS/1965 Tentang Pencegahan Penyalahgunaan dan atau Penodaan Agama. UU tersebut dijadikan landasan untuk pembentukan beberapa peraturan pelaksana tentang pengaturan kehidupan beragama yang bertentangan dengan

\footnotetext{
26 Tim Penyusun Naskah Komprehensif Proses dan Hasil Perubahan UUD 1945, Naskah Komprehensif Perubahan Undang-undang Dasar Negara Republik Indonesia Tahun 1945 Latar Belakang, Proses dan Hasil Pembahasan, 1999-2000, Buku VIII Warga Negara dan Penduduk, Hak asasi Manusia dan Agama (Edisi Revisi), (Jakarta; Sekertariat Jenderal dan Kepaniteraan Mahkamah Konstitusi, 2008), hlm.286.

27 Satjipto Rahardjo, Satjipto Rahardjo, Hukum, Masyarakat dan Pembangunan, Alumni, Bandung, 1980, 46

28 Id
} 
amanat konstitusi. Disisi lain terminologi agama atau keyakinan dalam perspektif hak asasi manusia tidak diartikan secara sempit dan tertutup, namun dikonstruksikan secara luas. Kesalahpahaman umum yang terjadi, biasanya menyatakan kepercayaan kepada Tuhan (teistik) sebagai yang disebut agama. Padahal Budhisme yang Non-teistik dan Hinduisme yag politeistik adalah juga agama.

Dengan demikian silang sengkarut regulasi tersebut menjadi muasal tercerabutnya nilai-nilai semangat demokrasi. Terlebih saat ini agama seringkali menjadi komoditi politik untuk memperoleh kekuasaan. Oleh sebab itu penting untuk mereformulasi atau setidak-tidaknya meninjau ulang dampak dari penerapan pasal penodaan agama di Indonesia.

\section{Prospek Pengaturan Rumusan Delik Agama Dalam Perspektif Ius Constituendum.}

\section{Sejarah Pasal 156a KUHP}

Salah satu hukum yang mengatur hubungan negara dengan warga negara adalah hukum pidana, yang merupakan bagian hukum publik. Hukum pidana sebagai salah satu bagian dari hukum publik merupakan salah satu instrumen hukum yang sangat penting dalam tatanan suatu negara. Keberadaan hukum pidana dipandang sangat penting karena fungsinya itu sendiri, yakni sebagai jaminan keamanan masyarakat dan ketertiban sosial. ${ }^{29}$

Dalam sejarah perjuangan kemerdekaan Indonesia, terdapat beberapa pasal yang dikenal dengan istilah Hatzaai Artikelen yakni Pasal 134,136 dan 137 KUHP sering digunakan untuk membungkam dan menjerat pejuang-pejuang yang menyuarakan kritik serta menyampaikan pendapat kepada pemerintah kolonial, serangkaian pasal-pasal yang sebenarnya terpaksa diberlakukan karena Indonesia belum dapat melakukan pembaharuan hukum pidana.

\footnotetext{
${ }^{29}$ Edi Setiadi dan Dian Andriasari, Perkembangan Hukum Pidana Di Indonesia, Graha Ilmu, Yogyakarta, 2013, hlm 32
} 
Sementara itu Wirjono Prodjodikoro ${ }^{30}$ menyatakan bahwa tindak pidana terhadap kepentingan agama dapat dibedakan menjadi dua:

1. Tindak pidana yang ditujukan terhadap agama (againts) adalah benarbenar membahayakan agama dan yang diserang secara langsung. Di sini perbuatan maupun pernyataannya sengaja ditujukan langsung kepada agama.

2. Tindak pidanayang bersangkutan/berhubungan dengan agama(relating, concerning) adalah tidak ditujukan secara lansung dan membahayakan agama itu sendiri.

Sebelum menjabarkan unsur-unsur dari Pasal 156a KUHP ini perlu disampaikan terlebih dahulu bahwa Pasal 156a KUHP merupakan pasal yang disisipkan dalam KUHP berdasarkan Penpres 1965 No. 1 Pasal 4 (L.N. 1965 No. 3). ${ }^{31}$

Sebagaimana isu yang berkembang pada Tahun 1965, diketahui bahwa Pemerintah orde Lama dituduh berafiliasi dengan partai politik beraliran komunis yaitu Partai Komunis Indonesia (PKI). Dalam perspektif politik hukum pidana, terbitnya Penpres tersebut menunjukkan sikap Pemerintah Orde Lama yang menepis isu tersebut.

Terlepas dari alasan penerbitan Penpres, pasal ini merupakan pasal sisipan dengan Penetapan Presiden era Orde Lama. Ada pihak yang mempermasalahkan Penetapan Presiden ini dan mengajukan gugatan ke Mahkamah Konstitusi tahun 2010, namun karena Penpres sudah dipilah-pilah oleh MPRS Orde Baru dan Penpres mengenai penodaan agama ini telah dinyatakan dapat diterima, maka telah mendapat status undang-undang. ${ }^{32}$

Oleh karenanya dengan sendirinya tidak ada padanan pasal ini dalam Ned. Wvs. Menurut Andi Hamzah, pasal ini merupakan khas Indonesia. Adapun bunyi

\footnotetext{
30 Wirjono Prodjodikoro, Tindak-tindak Pidana Tertentu Di Indonesia, Refika Aditama, Bandung, 1982, hlm 149

${ }^{31}$ R. Soesilo, Kitab Undang-Undang Hukum Pidana (KUHP) Serta Komentar-Komentarnya Lengkap Pasal Demi Pasal, Politeia, Bogor, 1994, hlm. 134

32 Andi Hamzah, Delik-Delik Tertentu (Speciale Delicten) Di Dalam KUHP, Sinar Grafika, 2015, Jakarta, hlm. 247-249
} 
Pasal 156a KUHP adalah:

Dipidana dengan pidana penjara selama-lamanya lima tahun, barang siapa dengan sengaja di depan umum mengeluarkan perasaan atau melakukan perbuatan:

1. Yang pada pokoknya bersifat permusuhan, penyalahgunaan atau penodaan terhadap suatu agama yang dianut di Indonesia;

2. Dengan maksud supaya orang tidak menganut agama apa pun juga yang bersendikan ke Tuhanan Yang Maha Esa

Menurut Andi Hamzah, menjadi pertanyaan yuridis ialah apakah bagian inti yang tercantum dalam huruf a dan b alternatif ataukah kumulatif? Dilihat dari maksud pembuat undang undang, mestinya ini merupakan alternatif bukan kumulatif. Artinya salah satu saja yang dibuktikan untuk dapat dipidananya pembuat. Dalam hal ini yang dilindungi disini ialah kebebasan beragama dan melaksanakan agama tanpa gangguan dari orang lain. ${ }^{33}$

Sedangkan pasal 154,155 dan 156 KUHP dalam sejarahnya sering disebut sebagai pasal Hatzaai artikelen ( pasal penyebar kebencian), rangkaian pasal yang mempunyai makna yang luas karena ia memuat larangan yang tidak saja menyangkut bentuk dari pernyataan-pernyataan melainkan pula melanggar secara formil kebebasan materil untuk menyatakan pendapat mengingat rumusan seperti kata-kata permusuhan, benci atau merendahkan dalam pasal-pasal tersebut memberikan ruang bagi interpretasi yang sangat luas. Pasal-pasal ini merupakan pasal yang tidak hanya melanggar kebebasan materil melainkan ia dapat menimbulkan penghinaan formil, penghinaan formil maupun materil tercakup di dalamnya sehingga ia tidak memungkinkan suatu kritik yang objektif sebagai suatu hal yang dibenarkan dalam kehidupan demokratis. Pasal 154,155 dan 156 KUHP sebenarnya di negeri Belanda pun mengalami gelombang penolakan.

Sebagaimana diketahui bahwa KUHP Indonesia merupakan adopsi dari KUHP (Ned.Wvs) Belanda pada saat itu yang diberlakukan di Indonesia berdasarkan asas konkordansi, namun menurut Andi Hamzah pasal tersebut (156 dan 156a) tidak ada padanannya dalam Ned. Wvs karena di Belanda tidak ada suku

33 Id 
bangsa, semua sama atau homogen, adat istiadat sama, bahasa sama, dan agama umumnya Kristen. Oleh karenanya pasal ini diatur di Indonesia dan perlu dipertahankan untuk mencegah gejolak sosial yang berbau SARA (suku, agama, ras dan antargolongan). Sebagaimana telah menjadi kenyataan bahwa Indonesia adalah negara yang plural/heterogen tidak homogen seperti Belanda

Oleh karenanya dengan sendirinya tidak ada padanan pasal ini dalam Ned. Wvs. Menurut Andi Hamzah, pasal ini merupakan khas Indonesia. ${ }^{34}$ Adapun bunyi Pasal 156a KUHP adalah :

Dipidana dengan pidana penjara selama-lamanya lima tahun, barang siapa dengan sengaja di depan umum mengeluarkan perasaan atau melakukan perbuatan :

1. Yang pada pokoknya bersifat permusuhan, penyalahgunaan atau penodaan terhadap suatu agama yang dianut di Indonesia;

2. Dengan maksud supaya orang tidak menganut agama apa pun juga yang bersendikan ke-Tuhanan Yang Maha Esa.

Sebagian sarjana yang berpendapat bahwa Pasal 156 KUHP tersebut pada huruf a dan b bersifat kumulatif, sehingga apabila salah satu huruf tidak terpenuhi maka tidak dapat dikenakan Pasal 156a tersebut. Dalam hal ini penulis sepakat dengan yang disampaikan oleh Andi Hamzah karena memang dalam perumusan pasal tersebut tidak secara tegas ditentukan apakah dirumuskan secara alternatif atau kumulatif sehingga membuka ruang untuk melakukan penafsiran terhadap pasal tersebut. Jika dicermati perumusan pasalnya dan juga maksud pembuat pasal tersebut maka dapat diketahui bahwa terdapat dua tindak pidana yaitu pertama, dengan sengaja di depan umum mengeluarkan perasaan atau melakukan perbuatan yang bersifat bermusuhan, penyalahgunaan atau penodaan terhadap suatu agama yang dianut di Indonesia dan kedua dengan sengaja dengan maksud supaya orang tidak menganut agama apapun juga yang bersendikan ketuhanan Yang Maha Esa. Meskipun demikian, dalam prakteknya, adanya celah ruang penafsiran tersebut akan menimbulkan persoalan baru, yakni ketidakpastian hukum dan keadilan yang merupakan cita ideal dari hukum itu sendiri.

${ }^{34}$ Supra no 32 , hlm. 250 
Unsur "maksud agar orang lain tidak menganut agama apapun juga bersendikan ke-Tuhanan Yang Maha Esa" itu merupakan suatu unsur tindak pidana kedua yang diatur dalam Pasal 156a huruf b KUHP, maka unsur tersebut juga harus didakwakan oleh penuntut umum di dalam surat dakwaannya, dan dibuktikan kebenarannya di sidang pengadilan. Tidak terbuktinya unsur tersebut telah dipenuhi oleh pelaku, akan menyebabkan hakim harus memutuskan bebas bagi pelaku. Ditinjau dari unsur objektif pasal tersebut, maka dapat dibedakan menjadi dua unsur objektif, yakni;

a. Pertama, pidana kedua yang diatur dalam Pasal 156a butir b KUHP ialah di depan umum. Sama halnya dengan unsur di depan umum sebagaimana yang dijelaskan diatas, di depan umum dalam rumusan tindak pidana tersebut itu tidak berarti, bahwa perasaan yang dikeluarkan pelaku atau perbuatan yang dilakukan pelaku itu selalu harus terjadi di tempat-tempat umum, melainkan cukup jika perasaan yang dikeluarkan pelaku itu dapat didengar oleh publik, atau perbuatan yang dilakukan pelaku itu dapat dilihat oleh publik. Walaupun perasaan itu telah diucapkan pelaku di suatu tempat umum, artinya suatu tempat yang dapat didatangi oleh setiap orang, akan tetapi jika perasaan yang ia keluarkan itu ternyata tidak didengar oleh publik, maka tindakannya itu bukan merupakan tindak pidana seperti yang dimaksudkan dalam Pasal 156a KUHP.

b. Selanjutnya, unsur objektif kedua dari tindak pidana kedua yang diatur dalam Pasal 156a KUHP itu ialah telah mengeluarkan perasaan atau melakukan perbuatan. Tentang perasaan mana atau perbuatan yang bagaimana, tidak dijelaskan bagaimana ukurannya, pembentuk undangundang ternyata tidak memberikan penjelasan, dan sepertinya telah diserahkan kepada hakim untuk menafsirkan dengan bebas perasaan atau perbuatan mana, yang dapat dipandang sebagai perasaan atau perbuatan agar orang lain tidak menganut sesuatu agama apapun juga, yang bersendikan ke-Tuhanan Yang Maha Esa. 
Perkembangan yang menarik hari ini adalah di era teknologi dewasa ini kerapkali membawa dampak negatif dalam kehidupan bermasyarakat, persoalan penodaan agama seringkali menajdi bias. Instrumen hukum lebih beragam salah satunya adalah apabila delik terjadi dalam media sosial maka dapat dikenakan undang-undang ITE. Kesulitandalam ranah pembuktian pasal penodaan agama seringkali membuat perosoalan menjadi makin meruncing di masyarakat, karena media sosial mempermudah orang atau sekelompok orang untuk melakukan perbuatan penistaan agama serta menyebarluaskan perbuatan tersebut. Akibat yang terjadi dari perbuatan tersebut selalu menimbulkan sentimen dan konflik antar umat beragama.

\section{Delik agama dalam Rancangan KUHP}

Pertanyaan mendasar yang seharusnya dikritisi bersama di ruang publik adalah apakah yang dimkasud dengan penodaan agama, selama ini narasi yang berkembang adalah delik agama, penistaan agama, kriminalisasi atas nama agama. Setidaknya penulis dapat mengidentifikasi istilah-istilah tersebut dari narasi media massa, manakala kasus-kasus dengan dimensi 156a KUHP mengemuka.

Secara Umum penodaan agama diartikan sebagai penentangan hal-hal yang dianggap suci atau yang tidak boleh diserang (tabu) yaitu, simbol-simbol agama/pemimpin agama/kitab suci agama. Bentuk penodaan agama pada umumnya adalah perkataan atau tulisan yang menentang ketuhanan terhadap agama-agama yang mapan. ${ }^{35}$

Dalam perspektif hukum pidana hingga saat ini, dalam RKUHP tidak ada definisi atau pengertian yang jelas mengenai penodaan agama. Baik Pasal 1 UU PNPS maupun Pasal 156 a KUHAP (pasal penodaan agama) juga tidak memberikan definisi ataupun penjelasan yang jelas soal penodaan agama. Karena itulah tafsir dari Pasal 156a KUHP dapat bermacam-macam. Kondisi semacam ini seringkali menimbulkan persoalan baru karena tidak adanya definisi yang jelas

\footnotetext{
${ }^{35}$ Pultoni dkk, Panduan Pemantauan Tindak Pidana Penodaan Agama dan Ujaran kebencian, ILRC, Jakarta, 2012 hlm 44.
} 
soal penodaan agama. Persoalan mendasarnya adalah apakah memberikan penafsiran berbeda terhadap suatu ajaran agama atau ayat kitab suci termasuk penodaan agama?.

Menurut pandangan penulis, bahwa soal penafsiran bukanlah merupakan bentuk penodaan agama. Karena "menafsirkan" itu sendiri merupakan bagian dari hak asasi manusia yaitu hak kebebasan berekspresi dan menyatakan pendapat yang dijamin dan dilindungi Konstitusi. Konsep-konsep abstrak seperti agama beririsan dengan ruang kebebasan sebagai seorang individu yang berdaulat atas pemikirannya diamping itu penafsiran adalah aktifitas menafsirkan konsep merupakan akivitas yang lazim dalam ranah ilmu pengetahuan (sebut saja dalam mata kuliah perbandingan mazhab, dijelaskan semua gambaran pemikiran dalam mazhab kemudian mahasiswa/i digerakkan untuk mengkritisinya). Apakah fase tersebut dapat dikualifikasi 'menodai agama tertentu?". Oleh karena itu ketiadaan batasan yang jelas mengenai bagaimana penodaan agama menjadi muasal dari silang sengkarut penerapan pasal ini.

Persoalan bagaimana negara membangun relasi dengan agama, atau sejauh mana negara menghegemoni melalui hukum (pidana) dalam mengurusi "agama". Hal tersebut pertama kali dicetuskan oleh Prof. Oemar Senoadji. SH. Embrio konsep formalisasi pengaturan agama oleh negara pertama kali di sampaikan oleh Prof. Oemar Senoadji, SH dalam Simposium "Pengaruh Kebudayaan dan Agama Terhadap Hukum Pidana" di Bali pada tahun 1975, dan dalam tulisan beliau berjudul "Delik Agama". Oemar Senoadji kemudian mengemukakan landasan beserta urgensi mengapa negara perlu mengatur persoalan agama. Landasan dan urgensi tersebut kemudian melahirkan beberapa teori-teori delik agama. Teori tersebut bermaksud menjelaskan landasan teoritik atau latar belakang pemikiran konsepsional mengenai perlunya dilakukan kriminalisasi terhadap delik agama. ${ }^{36}$

Beberapa catatan penting dari landasan teoritik tersebut diantaranya adalah, pertama RELIGIONSSCHUTZ-THEORIE (teori perlindungan “agama”). Menurut teori ini, "agama” itu sendiri yang dilihat sebagai kepentingan hukum

\footnotetext{
36 Oemar Senoadji dalam Barda Nawawi Arif, Delik Agama (revisi ke-5), Semarang, Badan Penerbitan Undip, 2008, hlm 1
} 
atau objek yang akan dilindungi (yang dipandang perlu untuk dilindungi) oleh negara, melalui peraturan perundang-undangan yang dibuatnya; landasan kedua disebut GEFÜHLSSCHUTZ-THEORIE (teori perlindungan "perasaan keagamaan"). Menurut teori ini, kepentingan hukum yang akan dilindungi adalah "rasa/perasaan keagamaan" dari orang-orang yang beragama; landasan ketiga FRIEDENSSCHUTZ-THEORIE (teori perlindungan "perdamaian/ketentraman umat beragama"). Objek atau kepentingan hukum yang dilindungi menurut teori ini adalah "kedamaian/ketentraman beragama interkonfessional di antara pemeluk agama/kepercayaan)" Jadi lebih tertuju pada ketertiban umum yang akan dilindungi. 37

Di dalam KUHP (WvS) selama ini tidak ada bab khusus mengenai delik agama, walaupun ada beberapa delik yang sebenarnya dapat dikategorikan juga sebagai delik agama dalam ketiga pengertian di atas. Delik agama dalam pengertian yang pertama (yaitu "delik menurut agama") banyak tersebar di dalam KUHP karena pada dasarnya sebagian besar delik dalam KUHP juga terlarang menurut agama, seperti misalnya delik pembunuhan, pencurian, penipuan/perbuatan curang, penghinaan, fitnah, delik-delik kesusilaan (zinah, perkosaan dan sebagainya). Artinya apa yang dilarang oleh KUHP juga merupakan hal yang juga dilarang dalam ajaran agama manapun.

Sedangkan delik agama dalam pengertian yang kedua terlihat dalam Pasal 156a (penodaan terhadap agama dan melakukan perbuatan agar orang tidak menganut agama). Oemar Senoadji memasukkan juga delik dalam Pasal 156-157 (penghinaan terhadap golongan/penganut agama; dikenal dengan istilah "group libel") ke dalam kelompok delik agama dalam pengertian yang kedua. Meskipun sebenarnya agak sulit untuk diterima apabila Pasal 156-157 dimasukkan dalam kelompok "delik terhadap agama", karena golongan/kelompok agama tidak identik dengan "agama". Akan sulit menentukan kualifikasi delik ini, sehingga pada prakteknya pasal ini akan mudah ditarik kedalam berbagai keadaan atau situasional dan rentan terhadap penyelendupan hukum. Keadaan ini akan sangat

37 Id, hlm.2 
berbahaya dan mengancam iklim demokrasi di Indonesia, terlebih mencederai marwah "negara hukum". Adapun pengertian delik agama dalam pengertian yang ketiga ("yang berhubungan dengan agama atau kehidupan beragama"), di dalam KUHP tersebar antara lain di dalam Pasal 175-181 dan 503 ke-2.

Memperhatikan pengaturan pasal-pasal KUHP tersebut, terlihat dengan jelas bahwa pada mulanya tidak ada delik yang ditujukan terhadap agama (pengertian delik agama kedua). Yang diatur dalam KUHP hanya delik-delik yang berhubungan dengan agama (pengertian ketiga), perkembangan selanjutnya yakni tahun 1965, dimasukkan "delik terhadap agama" (pengertian kedua) ke dalam KUHP, yaitu dengan ditambahkannya Pasal 156a ke dalam KUHP.

Ditinjau dari perspektif politik hukum pidana yang hendak ditujukan pada masa itu apabila dilihat dari redaksi perumusan tekstual pasal di atas, sangat jelas terlihat bahwa delik yang dirumuskan ditujukan terhadap "agama", bukan pada terganggunya perasaan agama atau ketertiban masyarakat pada umumnya. Penambahan Pasal 156a ke dalam KUHP itu berdasarkan Pasal 4 UU No. 1 Pnps. 1965 tertanggal 27 Januari 1965 yang pada awalnya berbentuk Penpres. Perumusan tersebut terkesan berlandaskan pada "Religionsschutz-theorie". Berarti ada divergensi atau ketidakharmonisan antara "status dan penjelasan delik" dengan "teks dan rumus delik". Inskonsistensi pasal 156a dapat dipahami dengan cara menelisik narasi akar (sejarah) reproduksi pasal tersebut. Suasana pergumulan politik dan sosial pasca gelombang perlawanan besar terhadap PKI pada September 1965.

Sebagaimana yang diungkapkan oleh Herbert Feith mengklasifikasikan secara garis besar aliran pemikiran politik di Indonesia setelah 1945 hingga periode Orde Baru; Komunisme, Nasionalisme Radikal, Sosialisme Demokrat, dan Islam. Agaknya kebijakan hukum (pidana) mencoba mengkonstruksikan Pasal 156a sebagai sarana untuk membendung perkembangan paham paham yang tidak sesuai dengan azas negara, disisi lain menarik agama dalam ranah politisasi. Meski dipahami kendaraan hukum (pidana) terbuka cukup luas untuk mengeksekusi 
ide-ide perlindungan azas negara agar tetap jernih dan kondisi sosial masyarakat akan selalu terkendali. ${ }^{38}$

Kebijakan kriminalisasi ditempuh dengan bertitik tolak dari pendekatan kebijakan praktis. Pendekatan praktis ini ditempuh mengingat kenyataan praktek penegakan hukum selama ini pun sudah mendasarkan kepada dua sumber bahan hukum (KUHP dan di luar KUHP). Namun pendekatan praktis ini pun tidak begitu saja ditetapkan tanpa seleksi dan evaluasi. Jadi, dilakukan juga pendekatan selektif dan evaluatif dan bahkan antisipatif sesuai dengan perkembangan masyarakat dan perkembangan Iptek. ${ }^{39}$

Hukum pidana yang identik dengan sanksi atau hukuman, pada dasarnya bertujuan untuk menciptakan keserasian dan ketentraman. Menurut Lawrence M.Friedman, bahwa; Sanction are ways to implement a norm or a rule. Legal sanctions are sanctions prescribed or authorized by law. Every legal rule contains or implies a statement of legal consequences. These consequences are sanctions promises or threats. Much of the social energy of law and much of society's investement in law goes support the system of imposing or threatening sanction; detective, police, bailiffs, prosecutor, and jails (on the criminal side) .40

Hukum pidana merupakan hukum sanksi istimewa, menerima sanksi sebagai rasionalitas dari adanya otoritas negara sebagai pelaksana kontrak sosial. Oleh sebab itu dapat dikatakan bahwa bangsa manusia rasional, memiliki perspektif yang khas dalam memahami dan melakukan atau ber-hukum. Umumnya, perspektif mengenai hukum yang ada pada setiap bangsa manusia rasional itu berbeda-beda sepanjang sejarah keberadaan bangsa itu berdasarkan nilai-nilai yang dianutnya menjawab tantangan zamannya ${ }^{41}$. Demikian pula

\footnotetext{
${ }^{38}$ Supra no 4, hlm. 36

${ }^{39}$ Barda Nawawi Arif, Bunga Rampai Kebijakan Hukum Pidana, Citra Aditya Bakti, Bandung, 2002, hlm. 246.

${ }^{40}$ Lawrence M. Friedman, Sistem Hukum Perspektif Ilmu Sosial, Nusa Media, Bandung, 2010, hlm. 198

41 Gambaran yang mendetail mengenai hal ini sudah menjadi pengetahuan umum; hanya saja sebagai bahan perbandingan, dapat dilihat dalam Danilo Zolo, The Rule of Law History, Theory and Criticism, Ed. Pietro Costa, Springer, 2007. Cf., atau bandingkan (bdk.) dengan yang dikemukakan Teguh Prasetyo, dalam Keadilan Bermartabat Perspektif Teori Hukum, Catakan Pertama, Nusa Media, Bandung, 2015, hal., 183-186.
} 
dengan kita bangsa Indonesia. Tercatat ragam perspektif usaha manusia Indonesia rasional mengenal hukum menghiasi khasanah filsafat hukum, keilmuan dan praktek hukum di Tanah Air. ${ }^{42}$

Masalah bagaimana masyarakat plural dapat menjadi stabil, tidak dapat dipecahkan, demikian Habermas dengan model dari teori liberal klasik Hobbesian yang disebut modus Vivendi. Dalam konteks problematik ini kita menempatkan debat penting antara liberalisme dan komunitarianisme. Para penganut liberalisme menegaskan kebijakan-kebijakan politis perlu dinetralisasi dari berbagai gambaran yang berbeda dan bersaing dari agama-agama, budaya-budaya (tentang jalan keselamatan; tentang the problem of justice). Sikap tidak netral dalam hal tersebut akan menyebabkan intoleransi dan penindasan pada minoritas. Kelompok mayoritas agama akan mudah tergoda untuk menjadikan alasan religius sebagai dasar pengambilan kebijakan politis. Sebaliknya, kaum komunitarian mengingatkan, bahwa manusia real selalu berasal dari dan terikat pada latar belakangnya, seperti etnis maupun religiusitas (Sunarko, 2011)

Pertanyaan mendasar yang timbul berdasarkan realitas tersebut adalah bagaimana seharusnya negara "mengurusi" agama. Sejauh mana urgensi campur tangan negara dalam mengelola kebebasan beragama. Apakah term "mengelola" sama dengan mengingkari hakikat kebebasan itu sendiri yang secara natural law adalah pemberian, sehingga logikanya negara hanya cukup untuk menjamin kebebasan saja.

Dalam Rancangan KUHP konsep tahun 2015 terdapat satu bab, yang berjudul; "Tindak Pidana Terhadap Agama dan Kehidupan Beragama”. Munculnya bab khusus ini sudah dimulai sejak konsep pertama Buku II tahun 1977 sampai dengan konsep 2014, merupakan upaya pembaharuan kebijakan hukum pidana di Indonesia, adalah wajar Konsep KUHP melakukan kajian ulang terhadap kebijakan KUHP warisan zaman Belanda yang menempatkan delik-delik yang berkaitan

42 Teguh Prasetyo, Keadilan Bermartabat Perspektif Teori Hukum, Catakan Pertama, Nusa Media. Bandung. 2015, hlm. 183-186 
dengan keagamaan ke dalam salah satu bagian dari delik terhadap "ketertiban umum". Pertanyaan mendasar dari realitas ini adalah apakah fakta bahwa agama menjadi salah satu objek" yang akan dilindungi oleh negara akan sejalan dengan cita konstitusi negara (jaminan kebebasan beragama)? Ataukah justru politik hukum pidana telah benar-benar secara nyata menghegemoni agama dan menjadikannya sebagai alat untuk politisasi belaka.

\section{Penutup}

Pengaruh penerapan Pasal 156a KUHP dalam kehidupan demokrasi di Indonesia berakar pada persoalan inkongruensi regulasi. Titik lemah dari penerapannya yang sangat kontradiktif dengan cita demokrasi. Persoalan tersebut bermula dari ketidaksebangunan pasal-pasal tersebut dengan jaminan kebebasan beragama/berkeyakinan. Kasus-kasus yang menimpa Ahok, Tajul Muluk menjadi realitas yang seharusnya direfleksikan dari penjatuhan pasal 156a KUHP. Silang sengkarut regulasi tersebut menjadi muasal tercerabutnya nilai-nilai semangat demokrasi. Terlebih saat ini agama seringkali menjadi komoditi politik untuk memperoleh kekuasaan. Kenyataannya pasal-pasal tersebut menjerat kalangan minoritas agama dan kepercayaan di Indonesia.

Sedangkan prospek pengaturan rumusan delik agama tercermin dalam rancangan konsep KUHP. Dalam Rancangan KUHP konsep tahun 2015 terdapat satu bab, yang berjudul; "Tindak Pidana Terhadap Agama dan Kehidupan Beragama”. Munculnya bab khusus ini sudah dimulai sejak konsep pertama Buku II tahun 1977 sampai dengan konsep 2014, merupakan upaya pembaharuan kebijakan hukum pidana di Indonesia. Adanya kajian ulang terhadap kebijakan KUHP yang menempatkan delik-delik yang berkaitan dengan keagamaan ke dalam salah satu bagian dari delik terhadap "ketertiban umum". Problem mendasar dari realitas ini adalah apakah fakta bahwa agama menjadi salah satu objek" yang akan dilindungi oleh negara akan sejalan dengan cita konstitusi negara (jaminan kebebasan beragama)? Ataukah justru politik hukum pidana telah benar-benar 
secara nyata menghegemoni agama dan menjadikannya sebagai alat untuk politisasi belaka.

Terminologi agama atau keyakinan dalam perspektif hak asasi manusia tidak diartikan secara sempit dan tertutup, namun dikonstruksikan secara luas. Rumusan Pasal 156a KUHP menimbulkan persoalan dalam menentukan apakah antara tindak pidana yang diatur pada huruf a dengan yang diatur pada huruf $b$ Pasal 156a KUHP, ditentukan secara kumulatif ataukah alternatif, maka dalam prakteknya masih terbuka peluang untuk diberikan penafsiran. Untuk itu titik lemah ini harus diatasi dengan perumusan yang lebih jelas (lex certa dan lex scripta). Politik hukum pidana harus menjadi pondasi kuat dalam membangun konstruksi pasal yang berpihak pada keberagaman dan tidak memberangus cita demokrasi itu sendiri. Sudah saatnya pasal-pasal yang berpotensi bertentangan dengan nilai-nilai HAM harus di reevaluasi dan di reformulasi. Hal tersebut merupakan upaya strategis dalam membangun hukum pidana sesuai dengan tujuan pembangunan hukum nasional yang berdasarkan Pancasila, merepresentasikan toleransi dalam kemajemukan.

Oleh sebab itu negara harus menjamin penegakan hukum yang tegas dan adil berdasarkan Pancasila dan Undang-undang Dasar 1945. Optimalisasi peran edukasi, sosialisasi dan literasi mengenai toleransi dan kerukunan serta pencegahan diskriminasi dan intoleransi dan kerukunan serta pencegahan diskriminasi dan intoleransi melalui optimalisasi televisi, media sosia sebagai ruang diskursus yang positif. Karena keterbatasan dari hukum pidana dalam menjangkau persoalan-persoalan di masyarakat. Disamping itu memperkuat dan mengintensifkan inisiatif dan pelaksanaan dialog yang setara anatar kelompok agama/ keyakinan.

Disamping hal tersebut upaya pembaharuan hukum pidana mutlak untuk segera dilaksanakan, agar Indonesia memiliki hukum yang linier dengan landasan ideologi negara, yakni yang berketuhanan yang maha esa, berkemanusiaan yang adil dan beradab dan berpersatuan, berdemokrasi dan berkeadilan sosial. 


\section{Daftar Pustaka}

Buku:

Barda Nawawi Arif, Delik Agama (revisi ke-5), Semarang, Badan Penerbitan Undip, 2008.

Barda Nawawi Arif, Bunga Rampai Kebijakan Hukum Pidana, Citra Aditya Bakti, Bandung, 2002

Bernard Arif Sidharta, Ilmu Hukum Indonesia, Jakarta, Genta Publishing, 2015.

David Betham, Democracy and Human Rights (Cambridge and Malden: Polity Press), 2000.

Deddy Mulyana, Metode penelitian kualitatif (Paradigma baru ilmu komunikasi dan ilmu sosial lainnya), Bandung, Rosda, 2003.

Edi Setiadi dan Dian Andriasari, Perkembangan Hukum Pidana Di Indonesia, Graha Ilmu, Yogyakarta, 2013.

Hannah Pitkin, The Concept Of Repsesentation, Berkley University Of California, 1967.

Koentjaraningrat, Kebudayaan, Mentalitas, Dan Pembangunan, Jakarta: Gramedia, 1985

Melissa Crouch, Asia Pacific Bulettin, Number 146, 2012

Supremasi Intoleransi, Setara Press, Jakarta, 2011, hlm.11

P.A.F Lamintang, Delik-Delik Khusus Kejahatan-Kejahatan Terhadap Kepentingan Hukum Negara, Bandung : CV Sinar Baru, 1998

R. Soesilo, Kitab Undang-Undang Hukum Pidana (KUHP) Serta KomentarKomentarnya Lengkap Pasal Demi Pasal(Bogor:Politeia, 1994).

Ronny Hanitijo, Metodologi Penelitian Hukum dan Jurimetri, Galia Indonesia, cet ke-4, Jakarta. 1990

Satjipto Rahardjo, Hukum, Masyarakat dan Pembangunan, Alumni, Bandung, 1980.

Taufik Amin Nur Wijaya, Hubungan Antara Islam Radikal Dan Terorisme, Kajian Timur Tengah Agama Dan Lintas Budaya Universitas Gadjah Mada 2014.

Teguh Prasetyo, Keadilan Bermartabat Perspektif Teori Hukum, Catakan Pertama, Nusa Media. Bandung. 2015.

Wirjono Prodjodikoro, Tindak-tindak Pidana Tertentu Di Indonesia, Bandung: Refika Aditama, 1982

Zainal Abidin Bagir, Pluralisme Kewargaan, Program CRCS UGM, Jogjakarta, 2016.

\section{Peraturan Perundang-undangan:}

Undang-undang Dasar RI Tahun 1945 Amandemen ke 4

Undang-undang No 1 Tahun 1946 tentang Peraturan Hukum Pidana (KUHP)

Undang-undang No. 12 tahun 2005 tentang Pengesahan International Covenant on Civil and Political Rights (ICCPR)

\section{Sumber Lain:}

Buku Saku VIII Warga Negara dan Penduduk, Hak asasi Manusia dan Agama (Edisi Revisi), (Jakarta; Sekertariat Jenderal dan Kepaniteraan Mahkamah Konstitusi, 2008), hlm.286 
http://nasional.kompas.com/read/2017/05/12/17225441/kritik.badan.dunia.so al.pasal.penodaan.agama.ini.tanggapan.polri

http://crcs.ugm.ac.id/id/artikel/10370/delik-agama-bagaimana-negaramelindungi-agama.html

http://indonesia.embassy.gov.au/jaktindonesian/kebebasan_beragama.html, 